\title{
A HAZAI ZÖLD CIVIL SZERVEZŐDÉSEK SZEREPE, LEHETŐSÉGEI A HELYI KÖRNYEZETI KONFLIKTUSOK MEGOLDÁSÁBAN STRATÉGIAI PEREK: SZÜKÜLŐ MOZGÁSTÉR?
}

\author{
(Green Groups/NGOs in Local Environmental Conflicts \\ in Hungary: the Strategic Lawsuits)
}

\section{GERGELY GYÖNGYI}

Kulcsszavak:

zöld civil szervezödések helyi környezeti konfliktusok stratégiai perek

Tanulmányunkban azt vizsgáljuk, hogyan változtak a zöld civil szervezödések poziciói a helyi környezeti konfliktusok 'menedzselését' tekintve az elmúlt közel negyven évben Magyarországon; javultak-e érdekérvényesitési esélyeik az új érában, vagy - akár saját hibájukból, a probléma komplexitásából adódóankezdeményezéseik eleve kudarcra vannak itélve. A téma azért (is) érdekes, mert nálunk is kezdenek divatba jönni az Észak-Amerikában és Nyugat-Európában már 'bejáratott' ún. stratégiai perek; ezeket mutatjuk be az elemzés utolsó blokkjában.

\section{A pártállami évek}

Hazánkban az 1970-es évek elejétól közel másfél évtizeden át kizárólag a hivatalos mandátummal rendelkezỏ, politikailag és anyagilag támogatott állami illetve társadalmi szervezetek (Hazafias Népfront, Kommunista Ifjúsági Szövetség, Magyar Úttörők Szövetsége, Szakszervezetek Országos Tanácsa stb.) 'szakmai' csoportjai foglalkoztak (?) környezetvédelemmel. A kádárizmus sajátos keretfeltételei miatt zöld pártok egyáltalán nem léteztek; az illegalitás mezsgyéjén - különböző konfliktusok kapcsán - szerveződött autonóm polgári kezdeményezések pedig informális mozgalmak, szubkultúrák formájában a 'második nyilvánosságban', szúk társadalmi bázissal múködtek (Ramet 1991). A mozgalmi létet kényszerból vállalták más, legális lehetőségek híján. Látens közösséget alkottak, hiszen a hatalom nagyjából azonos módon korlátozta öket a pénzügyi források elöteremtésében, a mobilizálást segítő szervezeti struktúra kialakításában. A hivatalos szervek tevékenységére a látványpolitizálás volt jellemző; a legkülönfélébb bizottságok létrehozásával, konferenciák szervezésével stb. jelezték a nyilvánosság, a külföld felé, hogy környezetvédelemhez kapcsolódó feladataikat 'letudták'. Valós tevékenységükröl azonban a lakosság szinte semmit sem tudott, mert a hatalom és a 'nép' közti kommunikáció - a társadalmi kérdéseket illetően - kizárólag egyirányú volt. Az ökológiai problémákat a 'szebb nevet adás' taktikájával elfedték; azonosításukból, a megoldásukra irányuló döntésekből a többség kirekesztődött. Mivel a politikai színezetet kapott ügyek csak politikai mezőben voltak értelmezhetők, az érdemi kom- 
Gergely Gyöngyi : A hazai zöld civil szerveződések szerepe, lehetöségei a helyi környezeti konfliktusok megoldásában. Startégiai perek: Szükülö mozgástér?

munikációhoz - konkrét esetekben - a zöld témákat is át kellett politizálni. Ezzel (is) magyarázható, hogy az alternatív, környezetvédő mozgalmak olyan ügyekre fókuszáltak, amelyek a közvélemény érdeklődését nagymértékben felkeltő voltuk miatt képesek voltak a politikai szereplés lehetőségét is biztosítani számukra. Sajnos ez a stratégia azóta is jó néhány szervezet múködésének elsődleges/kizárólagos mozgatórugója, ami visszahat a mozgalom egészének legitimációjára.

A nyolcvanas évek közepétỏl kezdtek megjelenni olyan új típusú, kifejezetten akciócentrikus 'képződmények', mint a Bős-nagymarosi erőmü elleni tiltakozás kapcsán alakult Duna Kör. A Duna Kör elöhírnöke volt a rendszerváltásnak. Miután az állam a vízlépcsővel kapcsolatos adatokat titkosította, az aktivisták mozaikokként gyüjtötték össze mindazt, ami tudható. Világossá vált, hogy erre a problémára nemcsak környezetvédelmi, de politikai válaszokat is adni kell (információhoz jutás szabadsága, társadalmi szervezetek bejegyzésére és müködésére vonatkozó jogszabályok hiánya stb.). A Kör 1985-ben - szakmai tevékenységének elismeréseként megkapta a The Right Livelihood Award-ot, az alternatív Nobel-dijat. Az ezzel járó pénzösszeg bankszámlán való elhelyezésének feltétele a szervezet bejegyzése lett volna, ami elörevetítette az egyesülési és gyülekezési törvény létrejöttét. A hatalom azt tanácsolta, hogy integrálódjanak az idöközben a KISZ KB keretei között létrejött környezetvédelmi tagozatba; ám ezt a változatot elutasitották, és kitartottak egy saját szervezet létrehozása mellett. Így 1989-ben ez volt az első bejegyzett társadalmi szervezet. Vita folyt arról, párttá alakuljanak-e, és bár abban egyetértettek, hogy az eröket koncentrálni kell, a kérdésben nem jutottak konszenzusra; ezért a tagok és támogatók a legkülönbözöbb pártokban találták meg a helyüket (Vargha 1989).

A Duna Körhöz hasonló szerveződések általános követelések jegyében léptek fel; azt a társadalmi, politikai struktúrát támadták, amelyben az állami környezetvédelem is létezett. A nyugati mozgalmak által meghaladott gazdasági-társadalmi modell létrehozását sürgették. Az államszocializmus alatt a civil szervezỏdések a nyugati társadalmakat tekintették mintának; még nem merült fel a piacgazdaság, a multinacionális vállalatok stb. kritikája. Nem is merülhetett fel, hiszen ezek nálunk még nem léteztek (Szirmai 1999).

$\mathrm{Az}$ egyre gyakoribbá váló zöld tüntetések, egyéb megmozdulások arra is lehetőséget adtak, hogy a lakosság az aktuális rendszerrel szembeni fenntartásait, ellenséges érzületét kifejezésre juttassa. Így a zöld mozgalmak elvileg igen kiterjedt társadalmi bázisra építkezhettek; ám valójában nem volt egyértelmü, kik a környezetvédelem igazi elkötelezettjei és kik azok, akik az akciókban pusztán a hatalom, a szocialista rendszer elleni tüntetés lehetőségét látják. A zöld mozgalmak politikaálcázó szerepe aztán a rendszerváltás után értelmét vesztette; ezáltal arra is fény derült, hogy a lakossági bázis valójában igen kicsi. 
Gergely Gyöngyi : A hazai zöld civil szerveződések szerepe, lehetöségei a helyi környezeti konfliktusok megoldásában. Startégiai perek: Szükülö mozgástér?

Tér és Társadalom 23. évf. 2009/3. 161-171. p.

TÉT XXIII. évf. 2009 - 3

Gyors ténykép

163

\section{Mi történt 1990 után?}

A kilencvenes évek elejétől a demokratizálódás új feltételeket teremtett; az addig informálisan müködő csoportok számára lehetővé vált, hogy tevékenységüket intézményes formában - párt vagy más politikai/társadalmi szervezet keretein belül - folytassák, bár a 'mozgalom vagy párt' döntést ez csak elvben könnyitette meg. A pártállam hivatalos struktúrája - monopolpozíciójának megörzése, átmentése érdekében hatalmi eszközökkel próbálta korlátozni, illetve versenyképtelenné tenni az alternatív szerveződéseket. Jól példázza ezt a Duna Kör egyesületalapítási kísérletének a joggal való visszaélés révén történỏ meghiúsítása (Sólyom 1985).

A fentebb említett látens közösség - a közös 'ellenség' eltünésével/megszűnésével felbomlott, összetartó eró nélkül maradt; az atomkonfliktus például, amely Németországban - a volt NSZK-ban - és még jó néhány államban mind a mai napig a legfontosabb integráló tényező, Magyarországon egyáltalán nem játszott/játszik szerepet (Flam 1994). A korábban egymással szolidáris mozgalmak gyakran szembekerültek, és még azok is veszítettek lendületükből, amelyek a nyolcvanas években látványos tiltakozó akciókat szerveztek.

A változás már 1989 első felében, a Németh Miklós által vezetett kabinet ténykedése alatt elindult; a rendszerváltást megelőző évtizedek talán legnagyobb 'dobásának', a Bős-Nagymaros konfliktusnak államközi/nemzetközi jogvitává válásával, átértékelődésével.

Magyarország és Csehszlovákia tárgyalásai a 'Dunaszauruszról' 1952-ben kezdődtek, a tényleges szerződéskötésre azonban csak 1977-ben került sor Moszkvában, az akkori szovjet elnök, Leonyid Brezsnyev 'atyai' közremúködésével. Az eredeti elképzelésekben szereplő létesítmények - a dunakiliti mederzáró duzzasztómü, a Csallóközben húzódó üzemvíz-csatorna, a vízlépcső stb. - tervezésénél energiatermelési, árvízvédelmi és mezőgazdasági/élelmiszer-elóállítási szempontok (az ezekből származó haszon) domináltak; a természet megóvása sokadrangú kérdés volt. Politikai-környezetvédelmi tiltakozások robbantak ki; a „végre tehetünk valamit” érzése, az ötletes jelszavak sokakat az ügy mellé állítottak. A kommunista rezsimet burkoltan támadó, százezres megmozdulások a beruházás mögül kihátrálni akaró Némethkormánynak is kapóra jöttek; jó ötletnek tünt mindent a zöldekre hárítani (a demokratikus szocializmus 'feelingjében' ez még a szovjet vezetés számára is elfogadható lett volna). Végül 1989-ben a magyar fél egyoldalúan felmondta a megállapodást, és leállt a dunakiliti, valamint a nagymarosi létesítmény építésével.

A szlovákok mindkettőt be akarták fejezni, akár egyedül, a csehek támogatása nélkül is. Elöbbi azonban megmaradt saját maga torzójának; a rendkívül drága, gyakorlatilag teljesen kész létesítményt ma sem használják (a szlovákok helyette Csúnynál hoztak létre saját duzzasztómủvet), a vízlépcsőt pedig az osztrákok építették tovább, a lebontásról szóló döntés megszületéséig - nekik a tartozást 2016-ig törlesztjük, áramban. 
Gergely Gyöngyi : A hazai zöld civil szerveződések szerepe, lehetöségei a helyi környezeti konfliktusok megoldásában. Startégiai perek: Szükülö mozgástér?

Tér és Társadalom 23. évf. 2009/3. 161-171. p.

164 Gyors ténykép

TET XXIII. évf. 2009

A konfliktus átsúlyozódása - az osztrák, illetve fóként az ellentétes csehszlovák, majd szlovák igényekkel szembeni artikulálódása - 1990 után már nem tette lehetővé széles körü, átfogó politikai tiltakozás megszervezését. Így egészen a Horn Gyula és Vladimir Mečiar vezette kormányok megegyezési kísérletéig, valamint a Duna Charta által létrehozott mozgalom megjelenéséig ez inkább ellenszakértői, propaganda, illetve információs tevékenységet jelentett; bár a Duna Kör utódszervezetei egy ideig még az építkezés körüli zürzavarból táplálkoztak (Mándi 1999).

A Bös-Nagymaros ügy ma sem 'alszik'; noha a magyar és a szlovák kormány az 1997-es hágai döntés óta - amely a folyóelterelést, valamint a vízlépcső-szerződés felmondását jogtalan cselekménynek minösítette, egyúttal körvonalazta a kölcsönös engedményeket - ezt 'szent tehénként' kezeli, és próbál a „ha nem tudunk megegyezni, hagyjuk egymást békén" mottó jegyében politizálni. 2007 októberében a szlovák elnök, Ivan Gasparovič úgy nyilatkozott bösi látogatását követöen, hogy hazánknak végre be kell látnia, sőt, nyíltan el kell ismernie: szükséges az építkezés befejezése, mert gazdaságilag elönyös, múszaki problémákkal nem kell számolni, a környezet pedig nem károsodott. További fejlemény, hogy a felek átfogó stratégiai hatásvizsgálatot terveztek, 2008 végéig (Bagyarik 2007).

A Duna-konfliktust követően lokális problémákra szakosodott tematikus, illetve regionális együttmüködések jöttek létre; ilyen volt az 1988-ban az ELTE Természetvédő Klub, a BME Zöld Kör és az Eszperantista Természetvédők által alapított Levegő Munkacsoport budapesti hálózata, vagy a győri Reflex Környezetvédő Egyesület (Kaiser 1999; Musza 1999). A lakosság, a civil szervezetek és más, a korábbi évtizedekben az ökológiához kapcsolódó döntésekböl (is) kizárt csoportok a legkülönfélébb akciók révén igyekezték tudatosítani: polgári társadalmat, modern környezetvédelmet akarnak. A felpezsdülést érzékelve többen úgy gondolták, az átmenet kiteljesedésével megsokszorozódnak majd az ilyen és ehhez hasonló követelésekre épülő konfliktusok, ám épp az ellenkezője történt; a politikai intézményrendszer megszilárdulásával, azzal, hogy a pártok, a minisztériumok stb. többé-kevésbé elfogadható válaszokat adtak a felmerülő problémákra, a nyilt konfrontáció veszített jelentöségéböl. Annak azonban, hogy az újonnan létrejövö helyi/regionális szerveződések képtelenek voltak a rendszerváltás adta mozgásteret kitölteni, más okai is voltak.

A magyar társadalom például ökoügyekben eleve megosztott volt; a szocialista gazdaságot jellemzó krónikus áruhiány megszünésével sokak számára a fogyasztás növelése jelentette az 'egyedül üdvözitő utat', ami a posztmateriális értékek megszilárdulása (kialakulása) ellen hatott. Hiányoztak a tömegmozgósításra alkalmas alternatív a hivatalos gazdasági-politikai eszmerendszertől eltẻrö, de nem depolitizált -, koherens, gyakorlatba átültethető módszerek; persze a komoly anyagi áldozattal jảró és/vagy az uralkodó piacorientált felfogásnak gyökeresen ellentmondó változtatási törekvések nem jöhettek szóba. Az ökológiai ügyeket leegyszerüsítve, néha kifejezetten sarkítva tálalták; a technikaellenes vagy etikai alapú megnyilvánulások sok esetben a vallásosság, a racionális-tudományos érvelések pedig speciális szakmai irányokba terelték a problémákat, érdektelenné téve ezzel bizonyos társadalmi csoportokat. A szennyezett településeken élők legtöbbször 'némák' maradtak; 
Gergely Gyöngyi : A hazai zöld civil szerveződések szerepe, lehetöségei a helyi környezeti konfliktusok megoldásában. Startégiai perek: Szükülö mozgástér?

Tér és Társadalom 23. évf. 2009/3. 161-171. p.

TÉT XXIII. évf. 2009 - 3

Gyors ténykép

165

egzisztenciaféltésböl tudomásul vették a helyben müködő vállalatok környezetromboló tevékenységét, így hiányzott az a bázis, amelyre a cégek adó- és foglalkoztatáspolitikájától, valamint az autonómiájukat korlátozó állami intézkedésektől erősen függő önkormányzatok legitim módon támaszkodhattak volna. A civil szervezetek tagjai nem számíthattak a parlamenti képviselókéhez vagy a pártaktivistákéhoz hasonló karrierre, ezért a kreatív mozgalomszervezök is egyre kevesebben lettek. Az egyesületeken stb. belüli munkamegosztás önkéntes vállalásokon alapult; a hierarchikus kapcsolatok hiánya azonban - a hatékony múködés szempontjából - inkább hátrány volt, mint elöny, nem is beszélve a személyeskedésekről, az erkölcsi támadásokról/támadhatóságról, a túlzott szereplési vágyról (Beliczay-Szirmai 2000). Az emberek informális elszigeteltsége, a média manipulatív információközlése, az új demokrácia bürokratizmusa, a szabadidő hiánya tovább csökkentette a politikai mobilizációs hálózatok kialakulásának esélyét; a környezetvédelmi tiltakozási potenciál csak ritkán testesült meg olyan, nagy tömegek érdeklódésére számot tartó rendezvényekben, mint a Föld Napja vagy a föváros XI. kerületében zajló út-ellenes (anti-road) megmozdulások.

A helyzet napjainkra alig változott; az ökológiai mozgalom ugyan sokszínü - lakossági és egyéb kezdeményezések -, de hiányzik a kapocs, az integráló erő, így a heterogenitás inkább fragmentálja a mozgalmat. Az állam visszavonulásával a gyenge támogatói bázisú, kevés pénzzel müködő, gyakran amatőr/próféta zöld szerveződések - amelyek léte, aktivitása továbbra is leképezi a településhierarchiát, vagyis nagyváros-centrikus! - tőkeerős, profi marketingeseket, kommunikációs szakértöket alkalmazó vállalkozásokkal állnak szemben; túl általános, nehezen operacionalizálható értékek ütköznek tehát jól artikulált érdekekkel. Az ökokérdéseket pozitív programok, illetve az ezek kidolgozásához, elfogadtatásához szükséges magatartás-modellek hiányában a zöldek gyakran politikaivá transzformálják, ami azt eredményezi, hogy egy-egy környezetvédelmi beruházásnak éppen ők lesznek a legföbb ellenzői. Az is előfordul, hogy egyszerüen szemet hunynak a hétköznapi természetrombolás felett (parkolóban leeresztett olaj, erdőben elásott akkumulátor stb.), mert érdekeiket jobban szolgálja a nagyobb volumenü, az országos média érdeklődésére is számot tartó ügyek (Duna-gát, atomerőmü) felvállalása.

$\mathrm{Az}$ állampolgárok jelentős részét a 'Not in my backyard' - attitüd jellemzi; vagyis elfogadják, hogy adott beruházásra - hulladéklerakóra, erőmủre, útra - szükség van, de a lakóhelyükön történö megvalósítás ellen határozottan tiltakoznak. Előfordulhat ennek az ellenkezője is, amikor egy országosan/globálisan környezetszennyezőnek ítélt létesítmény - autópálya, ipartelep - elhelyezése, építése érdekében lép fel a helyi közösség, mert azt remélik, a beruházás tényleges haszna ellensúlyozza majd a negatív hatásokat ('Put in my backyard'). Előbbinél világosan kirajzolódik az érintettek közti konfliktus, utóbbinál viszont ez hiányzik, illetve rejtve marad. A felügyelő szerveknek általában nem áll érdekükben ezt kiprovokálni; így az engedélyezési folyamatok sok esetben megfelelő kontroll nélkül zajlanak. Határozott kereteket adó ágazatpolitikára van tehát szükség, amely az elözetes befektetői szándékokat - a tartalmi és formai szempontok figyelembevételével - hatékonyan szüri, továbbá 
Gergely Gyöngyi : A hazai zöld civil szerveződések szerepe, lehetöségei a helyi környezeti konfliktusok megoldásában. Startégiai perek: Szükülö mozgástér?

Tér és Társadalom 23. évf. 2009/3. 161-171. p.

garantálja a felsőbb szintủ szakmai ellenőrzést úgy, hogy egyúttal kijelöli a lakossággal való egyeztetés formáit is; így elkerülhető, hogy a kormányzati, ágazati szervek magukra hagyva - elvakultan képviseljék saját szempontrendszerüket.

A társadalom tagjai még nem elég felkészültek/érettek ahhoz, hogy preaktív kezdeményezésekkel irányítsák sorsukat, hiszen általában az érdekeiket, életminőségüket közvetlenül veszélyeztető önkormányzati intézkedések, hatóságilag eltürt visszaélések ellen tiltakoznak; de öntudatosabbak, tájékozottabbak, hozzászólásaik pedig tárgyszerübbek, jogi szempontból megalapozottabbak, mint korábban. Esélyeik az érdekérvényesítésre, az érdekvédelemre az új érában sem javultak számottevően; gyakran évekig tartó, elkeseredett harcot vívnak a befektetökkel, a helyi közigazgatás szerveivel, mert hiányoznak az érdemi párbeszéd feltételei. A döntéshozatalnál nem teljes értékủ partnerek, javaslataikat, ötleteiket, elvárásaikat legtöbbször figyelmen kívül hagyják a tervek készítése során. A probléma tehát rendkívül összetett, kezeléséhez - a zöld szerveződések pozícióinak javításához - azonban több kell, mint a jogszabályok időnkénti módosítása.

\section{A stratégiai perek (SLAPP)}

SLAPP (Strategic Lawsuit Against Public Participation), azaz 'stratégiai per a társadalmi részvétel ellen' - hazánkban a környezetszennyező(nek gondolt) beruházásokban érdekelt cégek/befektetök 2006 óta sorozatban indítanak személyiségi jogi pereket a tiltakozó civilek, a zöldek képviselői ellen.

A deklarált ok minden esetben a jó hírnév megsértése; ám az érintettek szerint a megfélemlítési szándék több mint nyilvánvaló. A felperesek károkozóként általában nem az akciózó zöld szervezeteket, hanem azokat az aktivistákat nevezik meg, akik a legeredményesebben mozgósítanak a beruházás ellen. Azzal érvelnek, hogy a hitelrontás miatt projektjük zátonyra fut, így az összes addigi kiadásuk megtérítését követelik. Az eljárás mindig bizonytalan kimenetü; a sajátos 'dupla vagy semmi' játékban a beruházók legfeljebb a perköltséget veszíthetik el, ami aligha rengeti meg öket; az alperesek számára viszont a kudarc egyet jelenthet a teljes anyagi ellehetetlenüléssel (a hatástanulmányok, engedélyek megszerzése többmilliós tétel, ami a nagyobb szerveződéseket is padlóra küldheti, pláne egy-egy magánszemélyt). Azt, hogy mi számít a jó hírnév megsértésének, nyilván a bíróság dönti el; egy környezetvédelmi indíttatású szakmai fellépés esetén azonban nehéz kikerülni, hogy adott beruházás valószínủsített hatásait a nevükön nevezzék (környezetszennyezö, egészségkárosító, tájcsúfitó stb., amely állításokat bizonyítékokkal is alá kell támasztani, különben 'megállhat' a jó hírnév megsértésének vádja). A zöldek úgy vélik, ha egy ilyen perben elmarasztaló ítélet születik, helyrehozhatatlanul sérül a véleménynyilvánítás szabadsága. Lényegében épp abban akadályozzák/akadályozhatják őket - lekötve energiájukat, forrásaikat, idejüket -, ami a dolguk: független szakértőket bevonva, a lakosság szempontjait elötérbe helyezve mérlegelni egy-egy projekt környezeti kockázatait. A megoldást a véleménynyilvánítás határainak pontos kije- 
Gergely Gyöngyi : A hazai zöld civil szerveződések szerepe, lehetöségei a helyi környezeti konfliktusok megoldásában. Startégiai perek: Szükülő mozgástér?

Tér és Társadalom 23. évf. 2009/3. 161-171. p.

TÉT XXIII. évf. 2009 = 3

Gyors ténykép

167

lölése, továbbá olyan független intézmény létrehozása jelentheti, amely tudományos hitelességgel foglal állást a beruházásokkal, a technológiával stb. kapesolatban. Jelenleg ez ügyben az állami zöldhatóság mondja ki a döntő szót, elsö- illetve másodfokon gyakran homlokegyenest eltéró eredménnyel, igencsak megnehezitve ezzel az ellenzők, sőt, olykor a támogatók dolgát is (Hargitai 2007).

$\mathrm{Az}$ eddigi leghosszabb, legnagyobb horderejü, a nyilvánosságot erősen megosztó eljárást egyébként - világviszonylatban - a McDonald's kezdeményezte 1990-ben, a London Greenpeace nevü csoport két aktivistaja (Helen Steel és David Morris) ellen, akik 1986-ban „What's wrong with the McDonald's. Everything they don't want to know." címmel a gyorsétterem-lánc tevékenységét bíráló szóróanyagot juttattak el több ezer angliai háztartáshoz, utcai demonstrációkkal is hangot adva véleményüknek (a füzetecske a http://www.mespotlight.org/case/pretrial/factsheet.html oldalon is megtalálható). Többek között azzal vádolták a céget, hogy munkásait alulfizeti, megtévesztő reklámokkal (tápláló, vitamindús ételek?) próbál nagyobb forgalmat generálni, termékei pedig veszélyeztetik a fogyasztók egészségét. A hét évig tartó huzavona a felperes győzelmével zárult; az alpereseket összesen 24 ezer font kártérítés (hírnévrontás), valamint a perköltség megfizetésére kötelezték - bár tiltakozó akcióikat a bíróság erőszakos cselekménynek minősítette, a vállalat által valótlannak ítélt állítások közül jó néhány igaznak bizonyult ( $\mathrm{pl}$. a méltatlanul alacsony bérek). Az esetröl film is készült „McLibel” címmel 1999-ben (Delfino-Doy 2002).

Nézzük a magyarországi példákat. 2005 májusában a Levegő Munkacsoport elnöke, Lukács András ,Az Auchan csodái” címmel a kereskedelmi lánc egyes beruházásainak törvényességét firtató cikket jelentetett meg a Népszabadságban. A véleményeknek helyt adó rovatban közölt irásból - amely interneten is elérhető a http://nol.hu/archivum/archiv-362065 oldalon - megtudhatjuk többek között, hogy a budaörsi áruház kivitelezési munkáit egy ideig építési engedély nélkül végezték; a dunakeszi bevásárlóközponthoz vezető út megépítését pedig sokáig azért tiltotta a természetvédelmi hatóság, mert nyomvonala egy ökológiai szempontból védett lápon vezetett volna keresztül - ám egyszerre csoda történt, mondja a szerző, és a cég megkapta a szükséges dokumentumokat. Az M0-ás közpénzböl finanszírozott káposztásmegyeri csomópontja is a multinak jött jól (dunakeszi egységének megközelítése szempontjából); hiába tiltakoztak a helyi lakosok, a zöld civil szervezetek a felduzzadt gépjármüforgalom, a fokozott környezeti terhelés miatt, a bíróság az Auchan javára döntött. A cikk miatt, a jó hírnév megsértése okán a cég beperelte Lukácsot. Az elsőfokú bíróság a felperesnek adott igazat, és egymillió forint megfizetésére kötelezte a környezetvédőt, mert azt a látszatot keltette, hogy az említett beruházások korrupciógyanúsak. A döntést megfellebbezték, és 2006 szeptemberében a Fövárosi Ítélőtábla kimondta, hogy Lukács a véleménynyilvánítás jogával élt, amikor hangot adott aggályainak az építkezések jogszerủségével kapcsolatban; nem tényeket közölt, hanem adatokkal alátámasztott személyes véleményt, ráadásul bizonyítható, hogy valóban történtek szabálytalanságok, amit a cég részben el is ismert. A döntés precedensértékủ (Gergely 2006). 
Gergely Gyöngyi : A hazai zöld civil szerveződések szerepe, lehetöségei a helyi környezeti konfliktusok megoldásában. Startégiai perek: Szükülö mozgástér?

Tér és Társadalom 23. évf. 2009/3. 161-171. p.

168 Gyors ténykép

TET XXIII. évf. 2009 a 3

2007 júliusában a BEGAS Kraftwerk GmbH és a Biomassekraftwerk Heiligenkreuz Betriebs GmbH kezdeményezett eljárást az eisenstadti Tartományi Törvényszék és Járásbíróságon a Pro Natura St.Gotthard (PRONAS) nevü civil összefogás öt vezetőségi tagja ellen. A fó vád: a PRONAS a http://sznh.atw.hu/civil/d_index.html oldalon, illetve a saját honlapján közzétett egyik tájékoztató anyagában a felperesek jó hírnevét csorbító, üzleti hátrányt okozó félmondatot közölt. A zöldek szerint ezeket rosszul fordították, és szövegkörnyezetükböl kiragadva értelmezték; de nézzük részletesebben.

2007 márciusában a PRONAS aktivistái közel 200 tonna illegálisan tárolt kommunális hulladékra bukkantak a heiligenkreuzi biomassza-erőmủ közelében; 21 pontban foglalták össze azokat a gyanús körülményeket, amelyek arra utaltak, hogy ezt akár az erỏmüben is el lehetne égetni, sőt, egy hulladékgazdálkodási szakemberrel is megnézették a helyszínt, akinek ugyanez volt a véleménye. Észrevételeiket azonban nem tényként, hanem feltételezésként közölték. (A kifogásolt konkrét mondat: „... feltételezhető, hogy a biomasszával együtt hónapok óta égetnek szemetet is, szabálytalanul." (Forrás: http://sznh.atw.hu/civil/d_index.html) A vádirat a "feltételezheto" szót nem tartalmazta, így tényként állította be a leírtakat.) A PRONAS egyébként az illetékes osztrák hivataltól is vizsgálatot kért, még mielött eljuttatta volna hozzá a 21-es kiegészítő 'csomagot'; konkrét kérdéseikre azonban a három hónapos határidőn belül nem kaptak választ. A második vádpont a BEGAS egyik projekttájékoztatójában megjelent, a Heiligenkreuz-Szentgotthárd ipari parkot ábrázoló légi felvételhez kapcsolódik; az eredeti fotóról levágták a környező, sürün lakott területeket, a maradék szentgotthárdi, külső városrészeket pedig három felhö takarja, ami a nyomtatási minőség miatt úgy néz ki, mintha ott sem lennének épületek - ez a tény a tervezett hulladékégetỏ elleni széles körủ tiltakozás egyik fö érve. A PRONAS tett néhány megjegyzést a látottakkal kapcsolatban, „amely az alábbiak szerint (is) értelmezheto”" bevezetéssel. (A kifogásolt konkrét mondat: „A BEGAS már megint manipulál”. „Az eredeti képre mintha még egy kicsit rá is segítettek volna a nyomtatott anyagban" (Forrás: http://sznh.atw.hu/civil/d_index.html). Arra is céloztak, hogy nagy valószínüséggel ugyanilyen helyszíni ábrázolás szerepel majd a hatástanulmányban is (,...valahogyan így adhatják elő a kiválasztott helyszint a hatástanulmány során" [Forrás: http://sznh.atw.hu/civil/d_index.html]). Feltételezésük végül beigazolódott, mert a dokumentum egyetlen szót sem ejtett Szentgotthárdról, illetve Magyarországról; kizárólag Ausztriára korlátozódott.

A BEGAS szerint az említett félmondatokat több osztrák médium is átvette; a vonatkozó sajtóközleményeket azonban nem nevezték meg - követeltek ellenben fizetett hirdetések formájában sajtó-helyreigazításokat, forditási költségeket az egyébként 60 ezer eurós kártérítés mellé. A PRONAS szerint a cég számára kezdett egyre kínosabbá válni a hulladékégető elleni, erősödő civil fellépés, ezért akarták őket per útján megfélemlíteni, félreállítani, ellehetetleníteni. Szinte biztos volt, hogy vesztesként nem tudják majd kifizetni a felmerülö költségeket, ezért szorgalmazták a peren kívüli megegyezést, amely végül létrejött - a keresetet visszavonták -, és amelynek érdekében még a kifogásolt szövegrészeket is levették a honlapról, holott 
Gergely Gyöngyi : A hazai zöld civil szerveződések szerepe, lehetöségei a helyi környezeti konfliktusok megoldásában. Startégiai perek: Szükülő mozgástér?

Tér és Társadalom 23. évf. 2009/3. 161-171. p.

TÉT XXIII. évf. 2009 @ 3

Gyors ténykép

169

azok korrektek voltak. Azt viszont sérelmezték, hogy a befektető elözetesen nem kereste meg őket, hanem rögtön a bírósági utat választotta (Dröszler 2007).

Perbe fogták a Pusztazámorra tervezett - hazánkban egyedülálló - szennyvíziszapszárító és -égető ellen sikeresen fellépő civileket is, 2007 novemberében. A beruházást kezdeményezö UTILIS Kft. a 2007 márciusi eredményes, elutasító népszavazást követően azért nyújtott be keresetet Nyitray András, az Egészséges Zámorért Értékvédő Társaság szóvivője, Réder Ferenc helyi lakos és Lelkes Zoltán, a Budapesti Müszaki Egyetem docense ellen, mert azok mérgezö technológiát alkalmazó, környezet- és egészségkárosító üzemnek minösítették az eredeti elképzelések szerint évi 20 ezer - késóbb, igény szerint 120 ezer - tonna kapacitással múködö létesítményt, megsértve ezzel a cég jó hírnevét (Szuhi 2007).

Az ellenzők szerint a település már a Hulladékkezelö Központ megépitésével is óriási dolgot vállalt, hiszen annyi szemetet fogad be, amennyit több ezer év alatt sem termelne; nem értették, miért kell a fỏváros szennyvízproblémáját is a nyakukba venniük. A kommunális szennyvíztisztítóból származó, víztelenített, nem rothadó szennyvíziszap kezelésére és hasznositására szolgáló egység negatív hatásait ráadásul csak sejteni lehetett, mert a cég nem bocsátotta rendelkezésre a szükséges hatástanulmányt (ha egyáltalán készült ilyen). A helyi polgárok, önkormányzati képviselők közül többen szervezett üzemlátogatásra utaztak az osztrák Bad Vöslau-ba, ahol hasonló technológiával, jóval kisebb kapacitású egység müködik; az itt készitett beszámoló képein jól látszódtak a szennyezés hatásai: a kéményen füstgázok kimosódásának nyoma, a gépi keverés, a szálló toxikus porral fedett munkaeszközök és falak. A klórtartalmú tisztítószerek használatával szinte biztos, hogy az égetés során rákkeltő dioxinok, furánok keletkeztek volna. Nem lehetett kizárni, hogy veszélyes vegyianyag-megsemmisitéssel is foglalkozna az üzem, hiszen maga a technológia az ipari szennyvíziszap ártalmatlanítását is lehetôvé tette. A környező utakat terhelte volna a növekvő gépjármüforgalom, nem beszélve a fokozódó légszennyezésről. Tisztázatlan volt az égetésböl visszamaradó hamu sorsa is; valószínüleg veszélyes anyagnak minősítették volna, amit zárható, fedett lerakóban kell tárolni. A folyamatos ellenörző vizsgálatok lebonyolítására sem volt garancia (egy minta analízise kb. nettó 120 ezer forint; évi hússzal számolva ez már jelentős összeg). További járulékos hatásként lehetett számolni a helyi lakóingatlanok 10-15\%-0s értékcsökkenésével. Sokakat felháborított, hogy a polgármester a képviselők nevében támogatta, sőt, egyesek szerint kifejezetten szorgalmazta a beruházás megvalósítását, holott nem volt olyan testületi ülés, ahol a tagok egyöntetúen rábólintottak volna a dologra; nem álltak rendelkezésre konkrét számadatok sem, amelyek igazolták volna a település 'első emberének' azon kijelentését, miszerint Pusztazámor összességében csak nyerhet a projekttel. A beruházó cég szakértỏi elismerték, hogy a szennyviz tartalmazhat kórokozókat, de a többlépcsős tisztítási folyamat radikálisan csökkenti ezek túlélését, így nem fenyeget járványveszély. A sok kérdőjel miatt tehát a többség 'nemmel' szavazott; az alperesek pedig úgy látták: csak az Alkotmányban biztosított szabad véleménynyilvánítási jogukkal éltek, amikor a problémákra felhívták a figyelmet - a bíróság végül az ő javukra döntött (Bohus 2007). 
Gergely Gyöngyi : A hazai zöld civil szerveződések szerepe, lehetöségei a helyi környezeti konfliktusok megoldásában. Startégiai perek: Szükülö mozgástér?

Tér és Társadalom 23. évf. 2009/3. 161-171. p.

170 Gyors ténykép

TÉT XXIII. évf. $2009 \Xi 3$

Hazai vonatkozású a Verespatakon aranybányát tervező Rosia Montana Gold Corporation esete is; a kanadai cég a rosiamontana.org honlap miatt indított eljárást 2007 decemberében az Alburnus Maior egyesület ellen, mert véleményük szerint a romániai civil szervezetnek nem volt joga az említett néven internetes oldalt létrehozni - amelyet történetesen a magyarországi székhelyủ Egyetemes Létezés Természetvédelmi Egyesület üzemeltet, a Zöld Pók Alapítvány budapesti szerverén, így minimum megkérdőjelezhető az AM elleni per ésszerüsége (Szabó 2007).

Három év után, 2008 októberében, a helyi önkormányzat építési engedélyével szabad utat kapott a Holcim Hungária Zrt. Nyergesújfalura tervezett zöldmezős beruházása. A vállalat 2005 augusztusában jelentette be, hogy hozzávetölegesen 70 milliárd forintos költséggel Európa legkorszerübb cementgyárát hozná létre a településen; az átadást követő öt-tíz éven belül bezárnák az elöregedett, évi félmillió tonna éves kapacitással müködö lábatlani üzemet, és az ott foglalkoztatott 230 fö átvétele mellett 52 új munkahelyet teremtenének. A gyár az évi másfél millió tonna cement elobállitása mellett 75 ezer tonna hulladékot is elégetne a termelési folyamat során (Bogád 2008).

A hír komoly ellenállást váltott ki a helyi lakosok és a környezetvédő civil szervezetek körében. A környező települések: Esztergom, Mogyorósbánya, Tát, Tokod és Tokodaltáró az érvényes népszavazásokon elsöprő többséggel utasították el a tervet; a nyesgesújfalui ügydöntő népszavazás érvénytelen volt ugyan, de a megjelentek 67\%-a igent mondott a beruházásra. Alapvető kifogásként merült fel, hogy a létesítmény közvetlen környezeti hatásai az Esztergom-Dorog-Párkány térség egészét érintenék/érintik. Azt a területet, ahol korábban is voltak problémák; a 2004-es esztergomi vízszennyezés országos visszhangot kapott, de az itteni hulladéklerakó lángjaira is jól emlékeznek a helybéliek. Az Esztergomi-medence köré rajzolt tíz kilométeres sugarú körben találjuk a lábatlani és a párkányi papírgyárat, a párkányi hulladéklerakót, a Richter Gedeon gyógyszergyárát, a Baumit dorogi üzemét, a Zoltek szénszálgyárát, illetve a dorogi hulladékégetőt. A környék flóráját 'gazdagítja' továbbá a dorogi hőerőmüből kikerülő salak és a Suzuki-gyár oldószer-kibocsátása. A gyönyörủ tájképi adottságú vidék tehát, úgy tủnik, elérte ökológiai teherbíró képességének határát. Ráadásul a vonatkozó kormányrendelet értelmében új légszennyező forrást tilos telepíteni, ha a közvetlen hatásterületen a szennyezettség mértéke meghaladja az éves határértéket (Esztergom és Dorog esetében a szállópor-szennyezettség határérték feletti). A beruházás-pártiak legföbb érve az új munkahelyek létrehozása volt. Kérdés, hogy egy olyan kistérségben, ahol a foglalkoztatottsági mutatók nagyságrendekkel jobbak, mint másutt, a légúti és daganatos megbetegedések aránya viszont az országos átlagot meghaladóan nő évröl-évre, ez elegendő érv-e a telepités mellett; a high-tech gyár pedig háromszor akkora kapacitással müködne, mint elödje, így a korszerübb technológia ellenére is jósolhatóan nőni fog a szennyezőanyag-kibocsátás.

Mindenesetre a Holcim nem bízta a véletlenre az ügyet. A közvélemény megnyerése érdekében ígéretet tett arra, hogy a jogerős és végrehajtható építési engedély megszerzését követő hatvan napon belül létrehozza a 'Nyergesújfalu fejlesztéséért' közalapítványt, 300 millió forintos indulóvagyonnal; költségtérités címén további 100 millió forintot fizet az önkormányzatnak az együttmüködési megállapodás alá- 
Gergely Gyöngyi : A hazai zöld civil szerveződések szerepe, lehetöségei a helyi környezeti konfliktusok megoldásában. Startégiai perek: Szükülő mozgástér?

Tér és Társadalom 23. évf. 2009/3. 161-171. p.

TÉT XXIII. évf. 2009 @ 3

Gyors ténykép

171

írását követö 30 napon belül, és 2007. december 31-ig egy uniós szabványoknak megfelelő játszóteret, valamint extrém sportpályát is építtet a településen. Rajzpályázatot írt ki iskoláknak, a civil szerveződéseknek viszont perrel fenyegetỏ leveleket küldött, az esztergomi népszavazás eredményét pedig bírósági úton meg is támadta (Schiffer 2006). Végül, mint fentebb említettük, a sorozatos tiltakozások ellenére az engedélyt megkapta, így várhatóan 2010-ben évi 1,7 milliós kapacitással a cementgyár megkezdheti a müködést.

Bár hazánkban még kevés a SLAPP kategóriájába tartozó, lezárt esetek száma, nem árt, ha a zöld civil szerveződések, mint potenciális szereplők, tisztában vannak a módszer lényegi jellemzöivel; hatékonyabban védekezhetnek például, ha jogvédő szervezetekkel is együttmúködnek, illetve a többi társadalmi szervezet is szolidaritást vállal azokkal, akik ellen az eljárást kezdeményezték.

\section{Irodalom}

Bagyarik C. (2007) Áldozat a rendszerváltás oltárán: a Bős-Nagymaros sztori. http://www.hetek.hu/?q=node/13875 (letöltve: 2007.11.15.)

Beliczay E.-Szirmai V. (2000) Fórum a társadalmi részvételről. http://www.mtapti.hu/mszt/ 20003/beliczay.htm (letöltve: 2007.10.11.)

Bogád Z. (2008) Épülhet a nyergesújfalui cementgyár. http://index.hu/gazdasag/magyar/hlce081001/ (letöltve: 2008.12.05.)

Bohus A. (2007) Pusztazámor: lerakó után jöhet az égetó? http://www.greenfo.hu/hirek/ hirek_item.php?hir=15272 (letöltve: 2008.02.16.)

Delfino, M.-Day, M. (2002) Be Careful Who You SLAPP. MoBeta Publishing, Los Altos, California.

Dröszler F. (2007) A birodalom visszavág! http://www.kormend.hu/?ugras=hirolvaso\&hirszama=14879 (letöltve: 2008.02.16)

Flam, H. (1994) States and Anti-Nuclear Movements. University Press, London.

Gergely Zs. (2006) Legyözte a könnyezetvédö az Auchant. http://www.origo.hu/itthon/ 20060914legyozte.html (letöltve: 2007.05.12.)

Hargitai M. (2007) Perrel hütött zöldindulatok. http://nol.hu/archivum/archiv-472368 (letöltve: 2008.01.15.)

Kaiser T. (1999) A Reflex Környezetvédő Egyesület. - Szabó M. (szerk.) Környezetvédelmì civil kezdeményezések Magyarországon (1988-1998). Villányi úti könyvek, Budapest. 163-183. o.

Lukács A. (2005) az Auchan csodái. http://nol.hu/archivum/archiv-362065 (letöltve: 2008.03.19.)

Mándi T. (1999) A Duna Charta. - Szabó M. (szerk.) Környezetvédelmi civil kezdeményezések Magyarországon (1988-1998). Villányi úti könyvek, Budapest. 204-217. o.

Musza I. (1999) Levegö-munkacsoport. - Szabó M. (szerk.) Környezetvédelmi civil kezdeményezések Magyarországon (1988-1998). Villányi úti könyvek, Budapest. 90-110. o.

Ramet, S. (1991) Sacial Currents in Eastern Europe. Duke University Press, Durham.

Schiffer A. (2006) „Sem a füstje, sem a lángja” - Magyar Hírlap. 2006. május 31.

Sólyom L. (1985) A társadalom részvétele a környezetvédelemben. - Medvetánc. 4. 217-242. o.

Szabó A. (2007) Pofon a zöldeknek? - Stratégiai perek. http://zoldhullam.blog.fn.hu/ index.php?view=bejegyzes_oldal\&bejid $=33589 \&$ bejcim=Pofon_a_zoldeknek__Strategiai_perek\&todo $=1$ (letöltve: 2008.03.21.)

Szirmai V. (1999) A környezeti érdekek Magyarországon. Pallas Stúdió, Budapest.

Szuhi A. (2007) Perben az égetőt ellenzők. http://www.greenfo.hu/hirek/hirek_item.php?hir=17158 (letöltve: 2008.02.17.)

Vargha J. (1989) Duna Kör. - Bossányi K. (szerk.) Szólampróba. Láng Kiadó, Budapest. 60-68. o.

"What's wrong with the McDonald's. Everything they don't want to know." (1986) http:/www.mcspotlight.org/case/pretrial/factsheet.html (letöltve: 2008.03.19.) 